\title{
Flexural Skin Nevus
}

National Cancer Institute

\section{Source}

National Cancer Institute. Flexural Skin Nevus. NCI Thesaurus. Code C54660.

A nevus occurring in the flexural skin. 